\title{
Solid Waste Management Practice of Residents in Abuja Municipalities (Nigeria)
}

\author{
Kadafa, A.A \\ Department of Geography, Faculty of Social Sciences.Nasarawa State University Keffi, Nigeria.
}

\begin{abstract}
Environmental sustainability is a global issue that has received a lot of attention in developed countries. Its importance and relevance cannot be over emphasized, but yet it hasn't received the attention required in developing countries and seems menial compared to other problems facing the populace. It seems an issue far from the everyday person on the street, but in reality it's a ticking time bomb just waiting to explode. Municipal solid waste is generated daily with an average of 0.5-1.5 kg/daily per household. Municipal solid waste management has become a health hazard in Nigeria, which is yet to be tackled properly by the government and local authority. It seems less relevant and quite capital intensive, as well as being an area that immediate or long term revenue generation from the sector seems bleak. The everyday person on the street of Nigeria seems unaffected by the waste piles on the streets, around residential and nonresidential dwellings. Improper waste management poses the greatest health risk facing Nigerians. It is quite common to see waste in water ways, streets, storm drains, and gutters and around public places. Literature has attributed the lack of awareness and low perception of the populace as contributing factors of municipal solid waste management issues. There are large populated areas which don't have any solid waste collection services available to them, and the informal collection system existing consists of individuals whom collect solid waste from residents and dispose of it improperly, Which acts to further make issues worse. It is usual for African nations to believe there are more pressing needs of the population that need funding but we are running out of space to hide our garbage. The revenue spent on clearing improperly disposed waste and damages caused could be used towards setting up skeletal solid waste management service in areas where no solid waste management services are available. Improperly disposed solid waste has become an environmental and health hazard in areas like the suburbs of Abuja, the Federal Capital of Nigeria. A survey was carried out in FCT, Abuja towards establishing the solid waste management practice of residents in the Federal Capital and it determined areas within the resident's practice that affects the proper function of the existing system where applicable.
\end{abstract}

Keywords: Environment, Sustainability, Municipalities, Solid waste

\section{Introduction}

Solid wastes are the useless and unwanted products in the solid state derived from the activities of, and discarded by society. According to Tchobanoglous et al. (1993) the term municipal solid waste (MSW) normally is assumed to include all waste generated in a community with the exception of industrial process waste and agricultural waste. Sources as MSW include; residential, commercial, institutional, construction and demolition, municipal services excluding treatment facilities, treatment plant sites and municipal incinerators.Solid waste management is the organized and systematic channelling of waste through pathways that ensure disposal through acceptable public health and environmental safeguards. Proper management cannot be achieved without a well-designed waste management plan (Kofoworola, 2007). Waste management issues are global with its environmental and health impact visible in a lot of developing countries. Solid waste management (SWM) is an integral part of urban and environmental management in every city (Latifah et al., 2008). Currently municipal solid waste management (MSWM) is a globally challenging issue especially in developing countries, due to its adverse environmental effects (Latifah et al., 2009; Zamorano et al., 2009; Jalil, 2010; Adekunle et al., 2011). Mankind naturally depends on the environment to sustain their lives but solid waste is one of the three major environmental problems in Nigeria, and many other developing and even the developed countries are threatened by this (Ogu, 2000; Latifahet al., 2009; Jalil, 2010). The problem of solid waste is a historical one because man's existence is inextricably linked to the generation of waste (Momodu et

DOI: $10.9790 / 2402-11020187106 \quad$ www.iosrjournals.org $\quad 87 \mid$ Page


al., 2011). Thus waste management generally plays a significant role in the ability of nature to sustain life within its capacity. Solid waste management is a recurring challenge for local authorities and environmental bodies in many developing countries (Zamorano et al., 2009), with standards of waste management being poor and outdated. Lack of sufficient equipment to collect the waste has been identified as a major problem of urban MSW in cities (Kofoworola, 2007). Issues recurring that affect municipal solid waste management are; poor documentation of waste generation rates and its composition, inefficient storage and collection systems, disposal of municipal wastes with toxic and hazardous waste, indiscriminate disposal or dumping of wastes and inefficient utilization of disposal site space.

Solid waste management has emerged as one of the greatest challenges facing state and local government environmental protection agencies in Nigeria. The volume of solid waste being generated continues to increase at a faster rate than the ability of the agencies to improve on the financial and technical resources needed to parallel this growth. Due to factors such as increased rate of urbanization, illegal city structure and developments, rapid rate of population increase, rapid development, and changes in consumption pattern. Which have been directly (and indirectly) linked to the generation of enormous amount of waste, ranging from biodegradable to synthetic waste (Abuja-Citiserve, 2004 and Zamorano et al., 2009). In Abuja the rapid growing waste generation rates and high cost of waste disposal, depletion of landfill space and the problem of obtaining new disposal sites thereby resulting in open dumping are unresolved issues. This makes it difficult for waste management authorities to identify and create solutions (Gomez et al., 2009). Even though several policies and programmes have been put in place to manage municipal solid waste, they prove ineffective due to financial and human constraints (Abuja-Citiserve, 2004). Community participation plays an integral role in the success of any SWM system. This has gain a lot of recognition recently. In Asia, lack of environmental ethics and awareness contribute to the failure of solid waste management plans (Visvanathan \&Trankler, 2003). Environmental knowledge, education and awareness play an important role in the successful implementation of an effective municipal solid waste management system. The level of awareness and environmental education about potential hazards relating to a polluted environment is still very low (Ogbonnaet al., 2002). This is an area that seems neglected in the current municipal solid waste management system for Abuja. The ultimate goal is achieving environmental sustainability and individuals need to understand the importance of the issue before any plan can be successfully implemented and executed. Proper management of solid and liquid waste is important for public health, economic, environmental and political reasons, therefore deserving increased attention from the area councils and authorities due to the negative effect on public health, the environment and natural resources (Klundert \& Anschutz, 2001. It has become a necessity due to the issues mentioned above to have an overview and analyse the current state. This research will bridge the gap in the existing body of knowledge with regards to waste management in Nigeria by giving a holistic assessment into the current status of solid waste management practice in Abuja. This study is an initial effort to fill the gap between theoretical solid waste management in the country and practical solid waste management towards achieving a more sustainable and effective solid waste management in the Federal Capital. The results from this research will act as an initial framework toward strategic planning and periodic follow up assessment is required to further improve the system. In orders to achieve this, relationships will be examined thus from which recommendations developed. This will overall advance the concept of sustainability and sustainable waste management in Nigeria.

The general objective isto assess the solid waste management practice of residents in Abuja municipalities (Nigeria). This research will cover the study of solid waste management in the Federal Capital Territory municipalities using ISWM (integrated solid waste management) as an assessment tool. The area of this study is confined to the five area councils and one municipal area council that makes up Abuja. The focus of the survey aspect of the research will include all residents residing within these areas. Primary data will be collected through questionnaires using random sampling for the residential questionnaire. The field survey will be inclusive of all areas within research scope. The research boundaries of the study include the system elements of the integrated solid waste management system. 


\section{Literature Review}

Municipal solid waste management is a global issue and has proven a key challenge facing African countries. Municipal solid waste management constitutes one of the most crucial health and environmental problem facing African cities. Most cities spend $20-50 \%$ of their annual budget on solid waste management and only $20-80 \%$ of the waste is collected (Achankeng, 2003). The UNEP (2009a) states "The World Bank estimates that in developing countries, it is common for municipalities to spend $20-50 \%$ of their available budget on solid waste management (open dumping with open burning is the norm), even though $30-60 \%$ of all the urban solid wastes remain uncollected and less than $50 \%$ of the population is served. . In low-income countries, collection alone drains up $80-90 \%$ of municipal solid waste management budget. In mid-income countries, collection costs 50-80\% of total budget. In high-income countries, collection only accounts for less than $10 \%$ of the budget, which allows large funds to be allocated to waste treatment facilities". One of the consequences of population growth and globalization is increased waste generation (Zamorano et al., 2009). Generation varies between cities and city part in Africa, with reliable data being difficult to come by (Achankeng, 2003). This has become a concern for developing countries and is one of the greatest challenges facing environmental protection agencies in developing countries (Olufayo \& Omotosh, 2007; Gomez et al., 2009; Ogwueleka, 2009; Zamoranoet al., 2009).

Consumption patterns affect the generation of waste, and according to Keseret al. (2012) consumption patterns are affected by many factors relevant to socioeconomic, environmental and demographic conditions. The global waste generation was estimated at 318 million tons as of 2002, with an annual increase of approximately $6 \%$. Global solid waste generation is expected to reach about 518 million tons in 2008 and 585 million tons in 2010 (UNEP, 2002; Periathamby\& Hamid, 2009). Hoornweg\&Bhada-Tata (2012) in a world bank report estimates that at present almost 1.3 billion tons of MSW are generated globally every year, or 1.2 $\mathrm{kg} / \mathrm{capita} / \mathrm{day}$ and by 2025 this will likely increase to 4.3 billion urban residents generating about 1.42 $\mathrm{kg} / \mathrm{capita} / \mathrm{day}$ of municipal solid waste (2.2 billion tons per year). According to Ogbonnaet al. (2002) in Nigeria, domestic waste production is increasing and is compounded by a cycle of poverty, population explosion, decreasing standards of living, bad governance, and low level of environmental awareness.Improper solid waste management has contributed greatly to river pollution and also to climate change where decomposing solid waste produces methane gas (Jalil, 2010).Cities in Nigeria are critically affected by huge population fallouts, inadequate supplies of social amenities, and the inability of administrators to meet with the demand of expanding population clusters, critically affect cities in Nigeria (Momodu et al., 2011). Thus in Nigeria indiscriminate disposal and dumping of solid waste is a common practise in most residential areas. Apart from various diseases and toxic conditions inherent in and derivable from wastes products, the presence of waste degenerates the aesthetic value of the environment (Ogbonnaet al., 2002). Health problems associated with poor water quality arising from inadequate waste disposal and waste management practices include; typhoid fever, diarrhea, cholera, hepatitis, hook worm infestation, skin diseases, and malaria. With regards to waste management options there is a large body of literature on the potential adverse health effects of different waste management options, particularly from landfill and incineration (Rushton, 2003). According to Rushton (2003) most research has focused on the health of the population, particularly those living near a waste disposal site and the occupational health problems of the workforce involved in waste management.

In the 1980s, the capital of Nigeria was relocated from Lagos to Abuja, due to persistent environmental problems. These problems made Lagos unsuitable to remain the countries capital. These problems included traffic congestion, flooding, bad drainage system, bad municipal services and population explosion due to urban migration. Prior to the relocation of the capital a master plan for the new capital was designed to avoid the reoccurrence of the problems encountered with the previous federal capital but today rapid expansion has exceeded the anticipated master plan (Imam et al., 2008). The waste management plan being lost as the city growth and development deviated from the master plan. Although development and urbanization are desired in a city but when they exceed the available infrastructural facilities and plans in place, problems arise and with time if not resolved can become irreversible.

As countries urbanize, their economic wealth increases. As standards of living and disposable incomes increase, consumption of goods and services increases, which results in a corresponding increase in the amount of waste generated (Hoornweg\&Bhada-Tata, 2012).Presently the rapid population increase due to urbanization in Abuja metropolitan areas have caused difficulties for the state and local environmental protection in

DOI: $10.9790 / 2402-11020187106 \quad$ www.iosrjournals.org $\quad 89 \mid$ Page


providing an effective and efficient municipal solid waste management system (Olanrewaju \& Ilemobade, 2009;Zamorano et al., 2009). Urbanization affects land use and when not controlled causes the emergence of illegal structure and neighbourhoods which is characteristic of some areas within and outside the metropolis. This has ultimately affected the city plan, thereby affecting services. Services such as; waste collection and eventually leading to illegal dumping. The management of municipal solid waste has become a major environmental problem, especially for fast growing cities such as the current federal capital; Abuja, with generation amount increasing yearly (Ogwueleka, 2013). Illegal dumps in the middle of residential areas have become common, with odours and rodent. These open dumps cause health risks and reduce the aesthetic value of the surrounding environment, detoriation of the urban environment, as well as contaminate natural resource (Ogu, 2000). There are cases where these waste are dumped in streams or river channels (Adedibu, 1985). Abuludeet al. (2007) reported that developing countries are witnessing changes in ground water, which constitute a major source of portable water in Nigeria. Water contamination by leachate can transmit bacteria and disease, typhoid fever is a common problem for the people of developing nations. There is also the risk of vertical heavy metals transfer both to the ground water and to the above ground vegetation (Remonet al., 2005).

Recently community participation has been recognised as playing an integral role in the success of any SWM system. This has gain a lot of recognition recently with factors such as environmental awareness, knowledge, perception, attitude and willing ness governing community participation. Studies supporting this fact include;Longeet al. (2009), Olorunfemi, (2009),Lalita\&Sunita (2011), Bangaet al. (2011),Bangaet al. (2011), Ohakweet al. (2011), Amfo-Outet al. (2012)Sumukwoet al. 2012,Agwu, (2012) and Shapan\& Mohammad (2012). Figure 1 shows the theoretical framework used to carry out this research

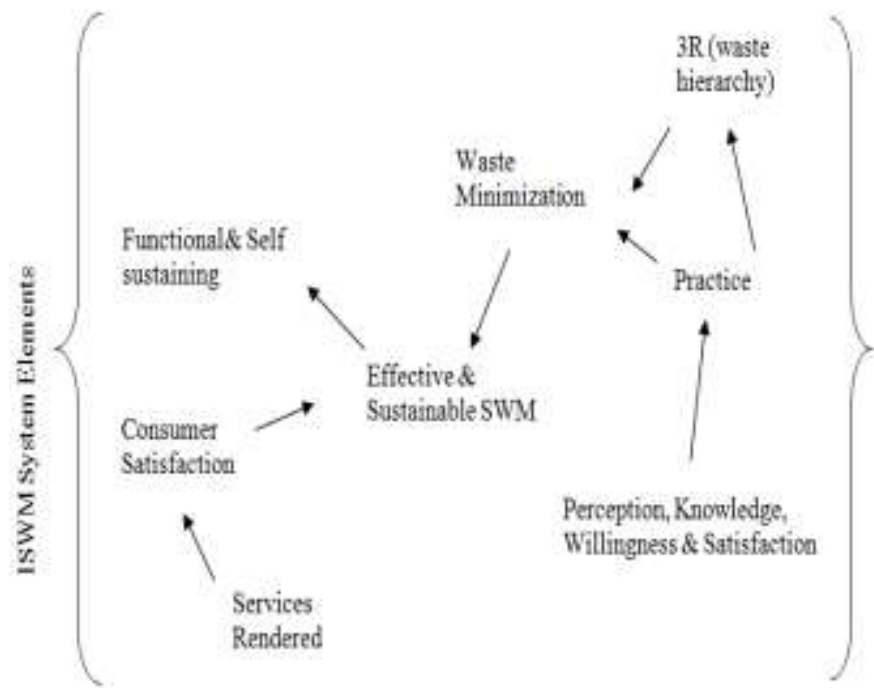

Figure 1: Research Theoretical Framework

\subsection{Study Area}

\section{Methodology}

Abuja; Nigeria's capital city is located in the middle of the country. The Federal Capital Territory has a land area of $8,000 \mathrm{~km}^{2}$. Abuja is bounded on the north by Kaduna State, on the west by Niger State, on the east and south-east by Nasarawa State, and on the south-west by Kogi State. It falls within latitude $7^{\circ} 25^{\prime} \mathrm{N}$ and $9^{\circ}$ $20^{\circ}$ North of the Equator and longitude $5^{\circ} 45^{\prime}$ and $7^{\circ} 39^{\prime}$ (www.fct.gov.ng).Abuja has a gentle undulating terrain rising from $305 \mathrm{~m}$ above sea level in the west to $610 \mathrm{~m}$ above sea level in the east.Interlaced by riverine depressions of the Usman River and its tributaries (Abuja-Citiserve, 2004).

\subsection{Research Methods and Techniques}

The sample frame consists of individuals residing within both case study areas. Data was collected using questionnaire survey and field survey. The construction of the research instruments is using ISWM as an assessment tool, which is used to outline the areas of assessment and the content of the survey. Klundert \& 
Anschutz (2001) in their study used the integrated solid waste management as an assessment/analysis tool for critical assessment. The residential questionnaire is closed, the study employed several statistical test meant for analysis and interpretation of data.he social package for social sciences (SPSS) version 20. The overall results based on the scope of the data; tabular and graphical format is used to illustrate and project various details (UNEP, 2009b).

\subsection{Sampling Strategies}

The sample frame consists of individual residing within both case study areas the areas was stratifies based on municipalities and districts. The questionnaires was distributed using simple random sampling within each stratus and distributed to households, within public places and parks in both cities. This sampling method was selected due to the large area, aimed at covering all the municipalities of the state; to enable a holistic and accurate assessment of the sample unit ( Kumar et al., 2009b).

\subsection{Study Area and Population}

Case Study I: Abuja consists of six municipalities; AMAC, Bwari, Gwagwalada, Kuje, Kwali and Abaji. The municipalities can further be subdivided into districts and areas. Abuja has a land area of 7,753.9 $\mathrm{Km}^{2}$, with a population of $1,406,239$ (NPC, 2012).

\subsection{Sample Size}

Sekaran (2010) proposed sample size should be larger than 30 and less than 500, which would be appropriate for research purposes. The sample size for the residential questionnaires was calculated from the formula below. This formula has been used to derive an appropriate size for the study area. A 95\% confidence level or $\mathrm{p}=0.05$ is assumed for Equation 3.1 (Krejcie\& Morgan, 1970; Fox et al., 2009):

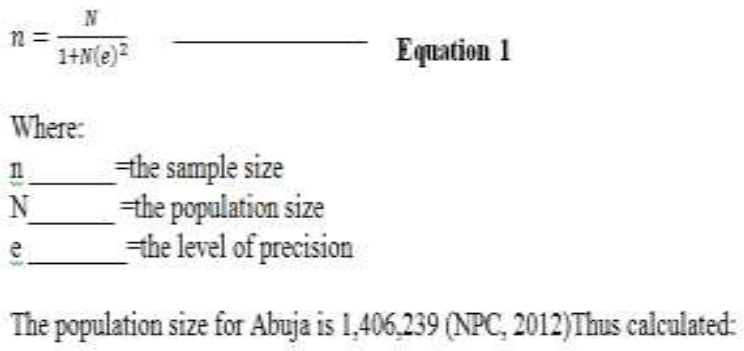

From the above formula and calculations, the sample size consists of approx. 400 for each case study. Large sample number is also recommended to ensure a higher statistical accuracy and confidence level (UNEP, 2009b; Gomez et al., 2009). According to Jacob et al. (1990) a large sample is much more likely to be representative of the population. In other words, the larger the sample sizes the smaller the error and the greater precision of the results (Cohen, 1988).

\subsection{Validity and Reliability}

The questionnaire was adopted from previous studies with modifications made to the residential questionnaire to suite this research. It was then validated by four experts. The questionnaire is tested via pilot study and retested after modifications are made.

\subsection{Instruments}

The scale selection consists of nominal scale applied to the categorical data.The questionnaires used for the research incorporated the components of the ISWMS which is used as a frame. The questionnaire will consist of close ended questions divided into sections as in Table 1. Section A consists of general demographic questions to establish age, sex, municipality, income and number of residents per household. Section B consists of questions that are categorised based on ISWM system elements, this will enable a holistic overview to identify not only the amount of solid wastes generated in the city, but also the solid waste management practice. 
It will be used to reflect parts of the current state of solid waste management based on the practice of the respondents in terms of waste generation, storage, collection, reduction, recycling and separation.

Table 1: Questionnaire Format

\begin{tabular}{|l|l|l|l|}
\hline Section & Item & Scale Type & No. Of Items \\
\hline A & Demographic Information & Categorical & 8 \\
& & & \\
\hline B & Waste Management Practices & Binary & 10 \\
\hline
\end{tabular}

\subsection{Field Survey}

This involved visits to all the municipalities in Abuja, three landfills within Abuja and one landfill site in Bwari under the Bwari area council. Also collection points located within different parts of Federal capital city were visited.

\section{Findings}

Demographic assessment is carried out using variables including; gender, occupation, age group, number of individuals per household, level of education and total family income. In Abuja $55.4 \%$ of the population comprises of males and $45.6 \%$ females. $59.8 \%$ of the population consist of government workers and $40.2 \%$ nongovernment workers. In terms of age groups, $12.4 \%$ were between the ages of $16-26 \mathrm{yrs}, 38.8 \%$ between $27-37 \mathrm{yrs}, 32.5 \%$ between $38-48 \mathrm{yrs}, 14.1 \%$ between $49-59 \mathrm{yrs}$ and $2.2 \%$ for $60 \mathrm{yrs}$ and above.In terms of level of education $2.9 \%$ of respondents has no educational qualification, $1.9 \%$ of respondents had primary school as their highest qualification, $9.1 \%$ of respondents had secondary school education, $18.7 \%$ had college education and $67.5 \%$ of respondents had university education. In terms of income level $8.5 \%$ of respondent earn between USD100-below monthly, 16.9\% earn between USD 101-200 monthly, 25.6 earn between USD201-400 monthly, 18.6\% earn between USD401-500 monthly and 30.4\% earn USD501-above monthly. In terms of number of individuals per household $5.8 \%$ of respondents live single, $10 \%$ of respondents have two individuals per household, $9 \%$ of respondents have three individuals per household, $16.5 \%$ of respondents have four individuals per household, $16.7 \%$ of respondents have five individuals per household, $14.8 \%$ of respondents have six individuals per household , $10.4 \%$ of respondents have seven individuals per household, $6.8 \%$ of respondents have eight individuals per household and $9.8 \%$ of respondents have nine individual and above per household.

Abuja has five area councils; Abaji, Kwali, Kuje, Bwari, Gwagwalada and one municipal area council; AMAC. Each area council is responsible for waste management within its individual jurisdiction. Each area council has an environment and sanitation/ public health unit in which waste management and public cleansing is one of the major responsibilities. AMAC which acts as the headquarters of the other five area councils is located in the centre of Abuja city. The Federal Capital City (FCC) in terms of waste management and pubic cleansing, it is carried out by Abuja Environmental Protection Board (AEPB) which is a parastatal under the Federal Capital Territory. Areas of jurisdiction and responsibilities of AMAC and AEPB within the FCC need to be clearly marked due to conflict in terms of duties to be carried out. The area councils lack the manpower or expertise to manage waste in the area councils so it is a usual site to find open dumps within residential area. Open dumps are a usual site within Abuja, within the FCC (Federal Capital City) there are a couple of them and when one moves away from the city centre they are more frequently cited. The waste management authorities blame the attitude and educational level of the populace for this, but when individual within the areas these open dumps are found were interviewed they blamed the authorities for infrequent collection and some areas entirely do not receive waste management services. Sumukwoet al. (2012) found over 57\% of residents attribute the challenge of household waste disposal to the inability of the municipality to collect the wastes frequently. AEPB operated 15 legal open dumps which are referred to as collection points.

In terms of the present waste generation as shown in Figure 2; percentage of daily household waste produce in Abuja ranges from $0.5-1.5 \mathrm{~kg} /$ daily. 


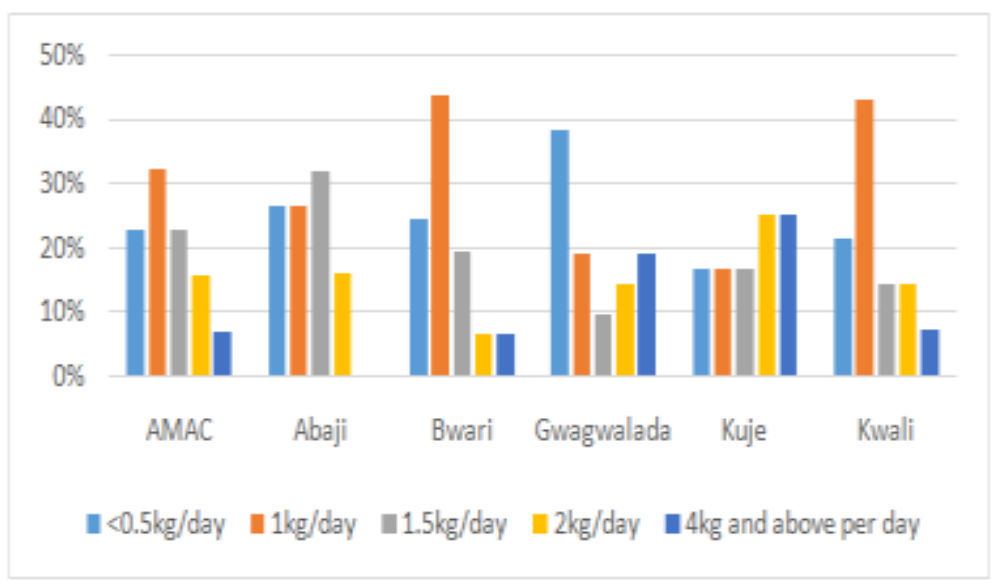

Figure 2: Estimated Daily Waste Generation per Household

AEPB estimates the average generation rate of MSW, inclusive of clinical waste is 14,784 tons per month and $0.45 \mathrm{~kg} / \mathrm{day} / \mathrm{capital}$ waste generation as of 2007 (AEPB, 2012). In Abuja bulk waste mainly consist of plastics, paper, glass, metal and other recyclable components; as shown in Table 2. The degradable portions of the waste consist of food waste and yard waste. Municipal solid waste and hospital waste are collected separately but are dumped/buried together. The waste composition consists of mixed waste inclusive of hospital waste.

Table 2: Municipal Waste Characterization for the Federal Capital City

\begin{tabular}{|l|l|l|}
\hline $\begin{array}{l}\text { Composition of Municipal } \\
\text { Waste }\end{array}$ & Quantity(tons) & $\%$ \\
\hline Paper & 16112.944 & 25.3 \\
\hline Textile & 1930.3099 & 3.03 \\
\hline Plastics & 5357.6878 & 3.40 \\
\hline Water sachets & 9257.8228 & 14.5 \\
\hline Glass & 2250.3883 & 3.00 \\
\hline Metals & 2642.8035 & 3.14 \\
\hline E-waste \& & 1786.329865 & 2.80 \\
\hline $\begin{array}{l}\text { Organic materials; food } \\
\text { garden waste }\end{array}$ & 42.60 \\
\hline Other organic materials & 1948.06 & 2.15 \\
\hline Total & 63707.107465 & 100 \\
\hline
\end{tabular}

Source: (AEPB, 2012)

From the results of the survey, Figure 3 shows the frequency pattern based on the type of waste produced. It can be seen from the radial graph plastic, paper and food waste have the highest percentages. Ogwueleka (2013) in his study of waste composition in Abuja reported organic wastes are the largest portion of the waste stream and $16.29 \%$ recyclable materials (paper, metals, glass, and plastic) on average.

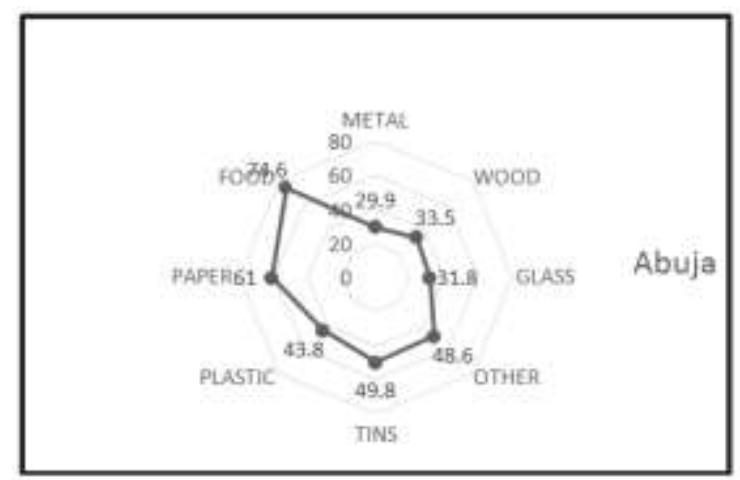

Figure 3: Pattern of Waste Compositions 
Waste collection is one of the first elements of a solid waste management system, in Abuja only $43 \%$ of individuals get their waste collected by AEPB or the area council with $42 \%$ using private collectors such as the pushers; young men who go door to door collecting waste for a fee (Table 3). The areas outside the FCC such as Bwari, Abaji, Kuje, Kwali and Gwagwalada, waste collection is available via using collection point in the case of residential non gated communities, offices and market areas. The residential areas consist of gated communities, community bins are placed in central areas where the residents are responsible for bringing their waste. The area council collects this waste for a fee. In areas covered by the area council, the collection points consists of an open dumps within the residential area which are periodically evacuated by the area council as shown in Figure 4.

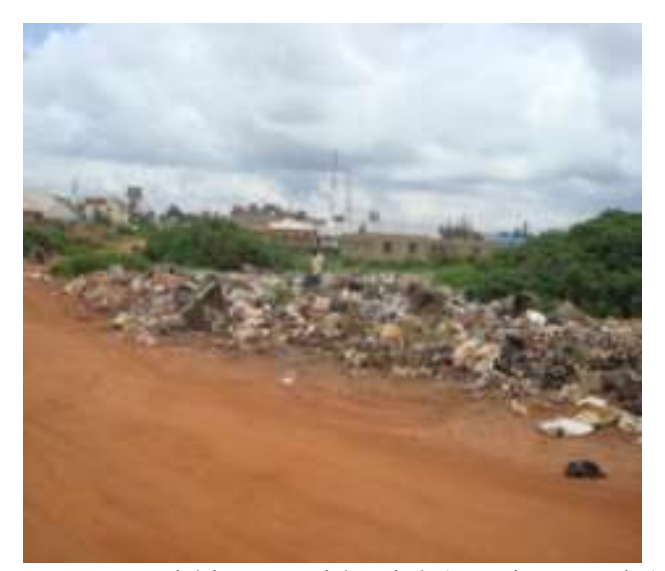

Figure 4: Open Dump within a Residential Area in Bwari Area Council

In terms of waste storage as shown in Figure 5 in Abuja, container/bins, plastic bags and bags are mostly used bag and containers/bin are used. In Abuja $29.7 \%$ of respondents have central community bins. $77.6 \%$ of respondents in Abuja say the bins provided are inadequate for their waste quantities.

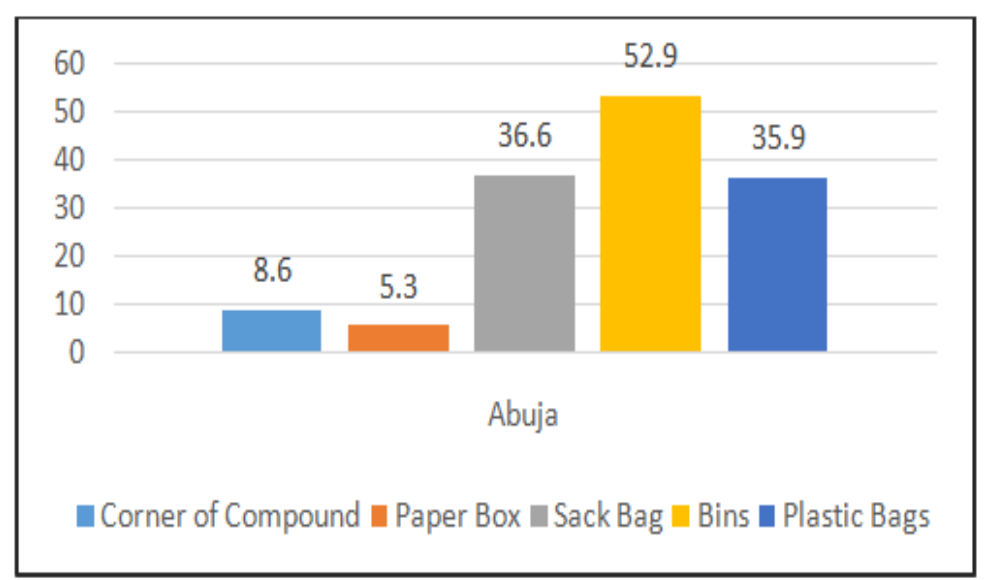

Figure 5: Types of Waste Storage by Residents

In Abuja $80 \%$ of the respondents have open dumps within their neighbourhood and areas where waste collection is provided by the AEPB, collections are irregular as shown in Figure 6. Figure 6 consist of the frequency of waste collection for Abuja, daily collections is $10.3 \%$, once weekly collections is $45.1 \%$, several times weekly collections is $7.8 \%$ and collections at longer intervals is $15.9 \%$. 


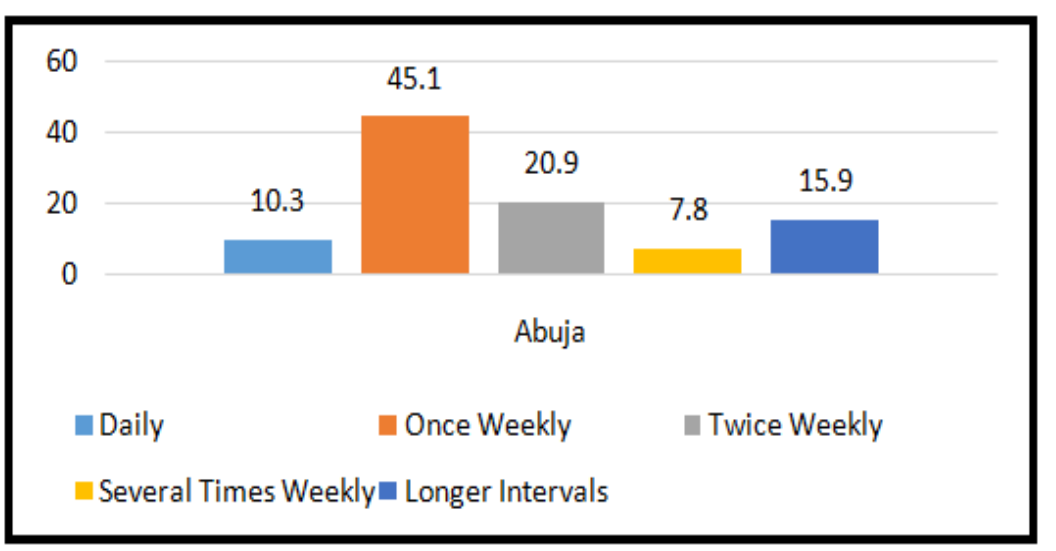

Figure 6: Frequency of Waste Collection in FCT, Abuja

It can be seen, the pattern of collection based on frequency, there are mostly once and twice weekly collections of waste. Recycling and reduction are waste minimization practices in the 3-R hierarchy system, which form the backbone of most waste management systems. In Abuja the percentage of respondents that practice waste reduction is at $22.7 \%$, while recycling is at $17 \%$ in Abuja and $78.4 \%$. Figure 7 shows the frequency of items that are recycled.

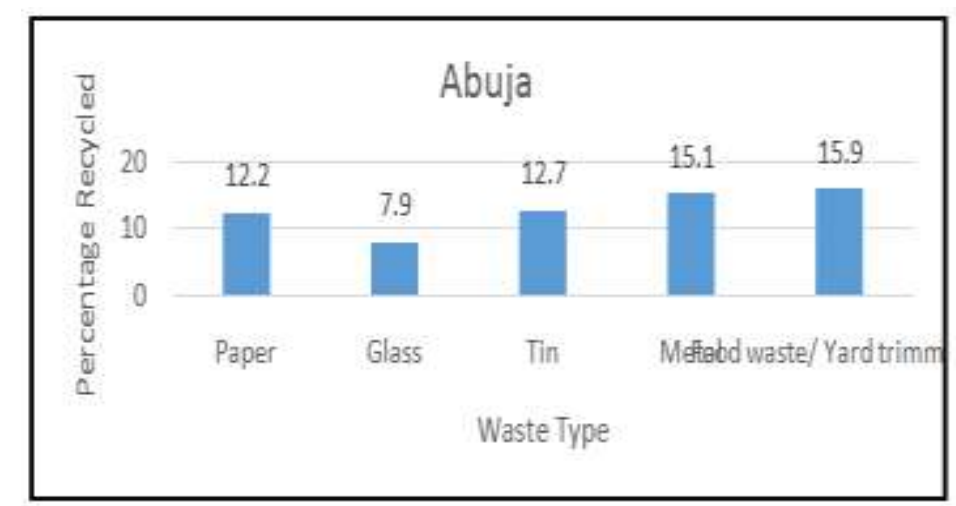

Figure 7: Frequency of Items Recycled

There is a high frequency for metal recycling as shown in Figure 7. Sumukwoet al. (2012) in their study of Eldoret municipality found $84 \%$ of the respondent's reuse the waste materials at home and $5 \%$ sell recyclable items.Presently,there is no recycling centres or proper transfer stations in Abuja. There are current plans to develop three transfer stations within Abuja, located at Kubwa, Apo and Mpape to serve the whole Abuja.The current solid waste management system for Abuja is shown in Figure 8.

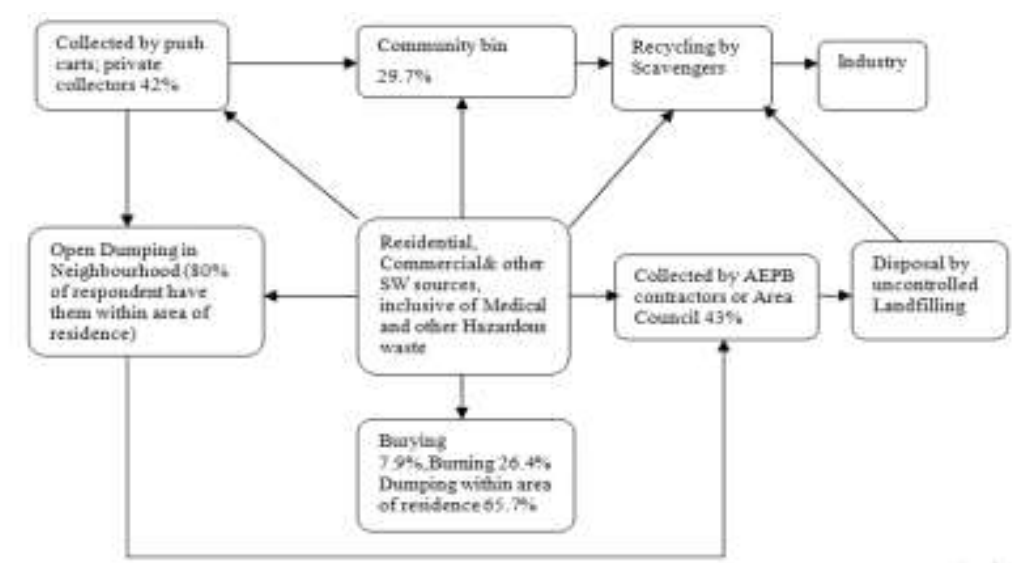

Figure 8: Solid Waste Management System in FCT, Abuja 


\subsection{Comparison of Solid Waste Management Practices among Residents}

Solid waste management practice among residents consist of different categories; storage, recycling, reduction, collection, separation at source, disposal, composting and general services. Proper disposal of solid waste constitutes a major problem in Abuja. Figure 9 is a bar chart showing the percentages of responses based on the different solid waste management practises.In Abuja $27.6 \%$ of respondents practise solid waste separation at the source of generation, $78.9 \%$ store their solid waste before collection or disposal, $26.4 \%$ dispose their solid waste by burning, $7.9 \%$ of respondents dispose their solid waste by burying, and $65.7 \%$ of respondents dispose their solid waste by dumping in the neighbourhood.

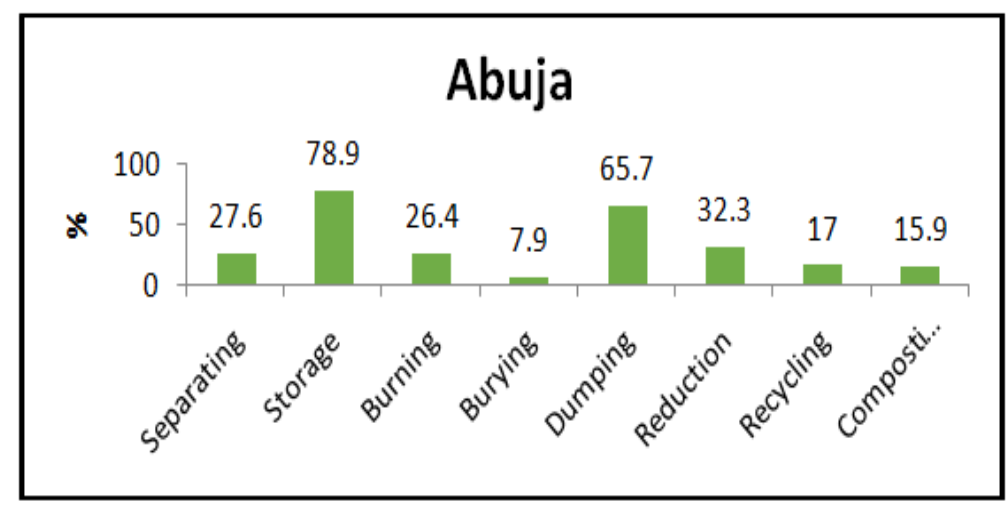

Figure 9: Frequency Based on Solid Waste Management Practices

In a study by Nabegu (2010) carried out in Kano State, Nigeria. It was observed that wastes were dumped in the open space on the street at close proximity to the houses and public places and some were dumped very close to the river, while others were dumped right into the river, especially in the city and the suburban zones. The study found $66.25 \%$ of residents dispose their waste by dumping in unauthorized areas with neighborhoods and 3.75\% burn their solid waste. Bangaet al. (2011) in their study of solid waste collection in Kampala, Uganda found $18.9 \%$ of respondents dispose their waste by dumping in the neighborhoods and burning , $18.9 \%$ bury their solid waste and $22.8 \%$ have their solid waste collected by the municipality. Sumukwoet al. (2012) in their study found $47 \%$ respondents dispose their waste in open dumps within their neighbourhood, $5 \%$ burn their solid waste and $49 \%$ bury their solid waste.In terms of waste minimization practises as shown in Figure 9, in Abuja 32.3\% of respondents practice waste reduction, 17\% of respondents recycle and $15.9 \%$ of respondents compost organic waste.

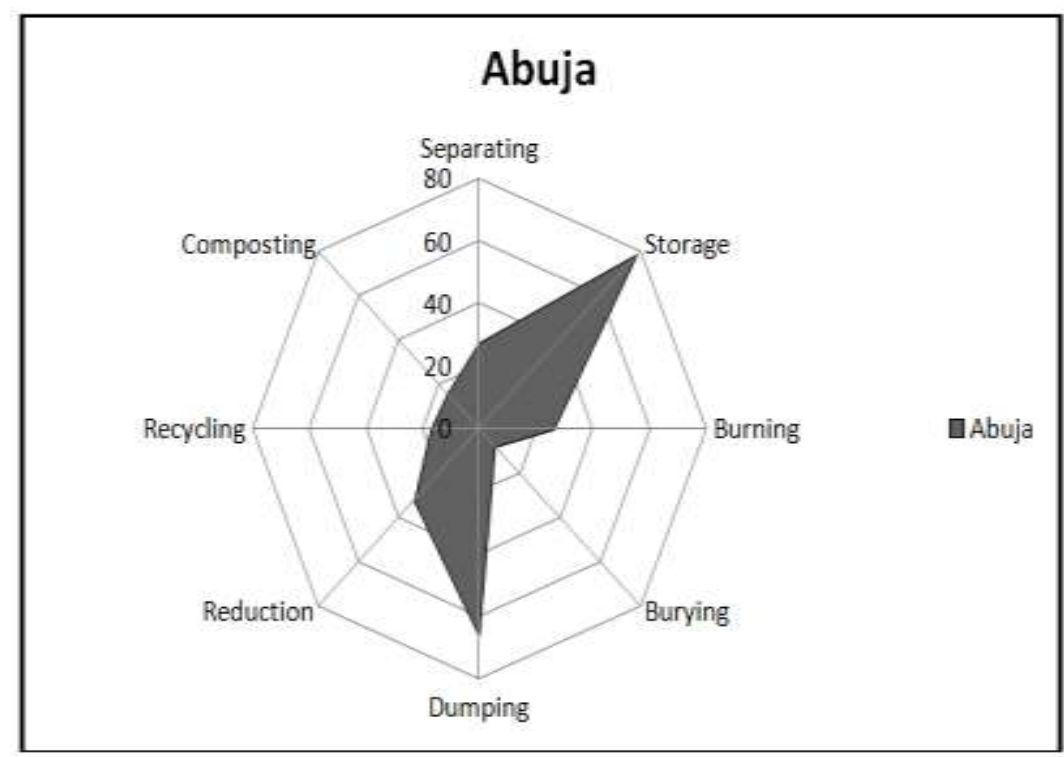

Figure 10: Radial Diagram Showing Pattern of Solid Waste Management Practises 
From Figure 10 it can be seen from the pattern; solid waste separation, solid waste dumping, solid waste burying and solid waste burning predominantly practiced in Abuja. From the survey results shown on Table 3 only $43 \%$ of the respondents in Abuja have waste services available to them. This is reflective of unsustainable solid waste management practices in Abuja. The high percentages obtained for unsustainable practices is reflective poor services available to residents, lack of knowledge with regards to health effect of these unsustainable practices.

Rahji\&Oloruntoba (2009) in their study of urban residents of Ibadan, Nigeria found about $15 \%$ of the households use municipal dumps. The most common disposal method is the empty plots/uncompleted buildings by $75 \%$ of the households, dumping by highway bushes/streets $60 \%$ and disposal by private firms $2 \%$. About $58 \%$ of the households used any drainage/streams/ponds and 55\% of the households used recyclable collectors to disposeof some household waste materials which had economic value. Results indicate that households had more than one illegal and unhygienic refuse disposal dump within the neighborhood. Nabegu (2010) found only $20 \%$ of the residents in Kano State, Nigeria received solid waste collection services by the municipality.

Table 3:Result Summary from Residential Solid Waste Practise Assessment

\begin{tabular}{|l|l|}
\hline Practise & Total \% Abuja \\
\hline Solid Waste Separation at Source & 27.6 \\
\hline Solid Waste Disposal by Burying & 7.9 \\
\hline Solid Waste Disposal by Burning & 26.4 \\
\hline Solid Waste Disposal by Dumping & 65.7 \\
\hline $\begin{array}{l}\text { Solid Waste Disposal by Municipal Collection } \\
\text { Services }\end{array}$ & 43 \\
\hline Solid Waste Disposal by Private Contractors & 42 \\
\hline Composting & 15.9 \\
\hline Reduction & 32.3 \\
\hline Recycling & 17 \\
\hline
\end{tabular}

Waste management practices are different in Abuja is high rate of open dumping and unsustainable practices by resident is attributed to lack of service availability and long intervals between collections when collection services are available.

\subsection{Summary of Findings}

In terms of solid waste management practises, in Abuja only $42 \%$ of residents have collection services available to them provided by the municipality. Recycling is also not well advanced in $17 \%$ of population recycle. In Abuja residents practice more unsustainable waste management practices; waste burning and dumping with neighbourhoods, Abuja residents show a higher percentage for waste separation and waste reduction which is more reflective of the harsh economy of the country. Where waste separation is carried out towards earning extra cash through selling the items in demand to scavenger and waste reduction is carried out due to the scarcity and high cost of food. Waste minimization still is an issue that has not been addressed in Abuja and strategies need to be implemented to increase the rate of recycling, composting and reduction of waste that requires final disposal.Open dumping within neighbourhoods is a common practise in Abuja at $80 \%$. The open dumps in FCT can be attributed to the irregular frequency of waste collection and waste collection services are not available in all districts. The frequency of daily waste collectionby the municipality is $10.3 \%$.

\section{Conclusions}

Municipal solid waste management is fast becoming an environmental issue in Abuja, with current practises being unsustainable resulting in visible environmental hazards. Agwu (2012) also found similar finding in his study which concluded Port-Harcourt city residents' waste management practices are unsustainable. There is no clear system for waste management in Abuja. Many issues and problems have been identified in the course of this research study. It is of importance for a basic waste collection service to be established and available in all districts of the federal capital with a separate management system for hospital waste. This will prove a difficult task when the institutional body is not integrated and laws are not clearly stated or comprehensive guideline needs to be adopted or formulated, modified for each aspect of waste management processes. Towards enabling staff to follow clearly stated duties and procedures. The institutions responsible for waste management 
need to be integrated under a single body with the proper instrument put in place to enable its proper function (guidelines). If solid waste management in Abuja is to succeed, sustainable approaches in all areas of waste management need to be integrated into the system. It is quite clear that solid waste management has become an environmental threat in Abuja, residents have become quite aware of the situation, but how possible is it to find a permanent solution in a system that has no assessment. According to Ogwueleka (2013) a successful solid waste management system depends on proper planning and design of the system using accurate planning tools and reliable data. There is a great need for assessment of the present and future trends carefully towards facilitating and implementing long-term planning.

\subsection{Photographs of the Study Area}

Abuja Municipal Area Council (AMAC)

AMAC Orozo and Jikoyi District District

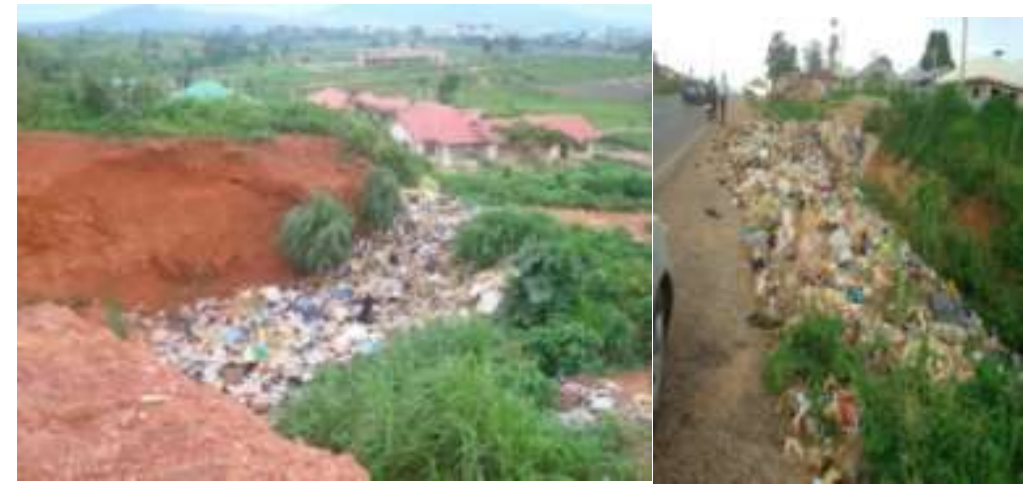

AMAC Nyanya District

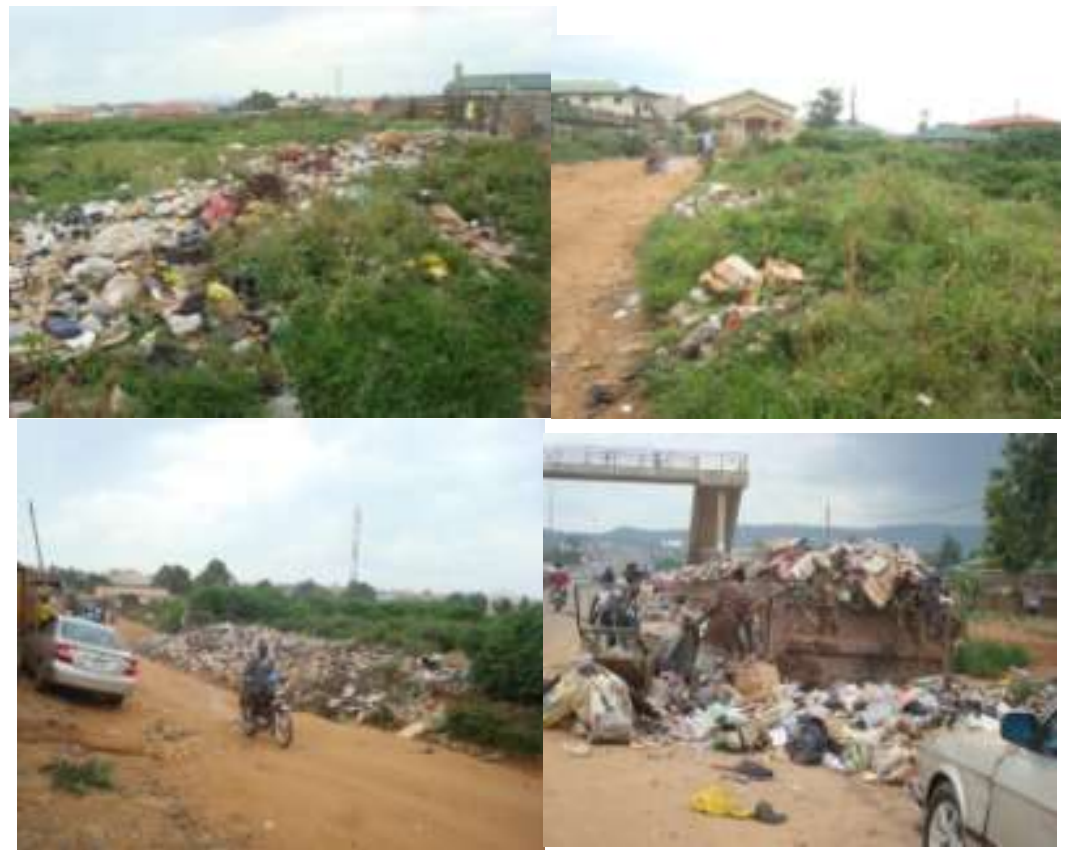



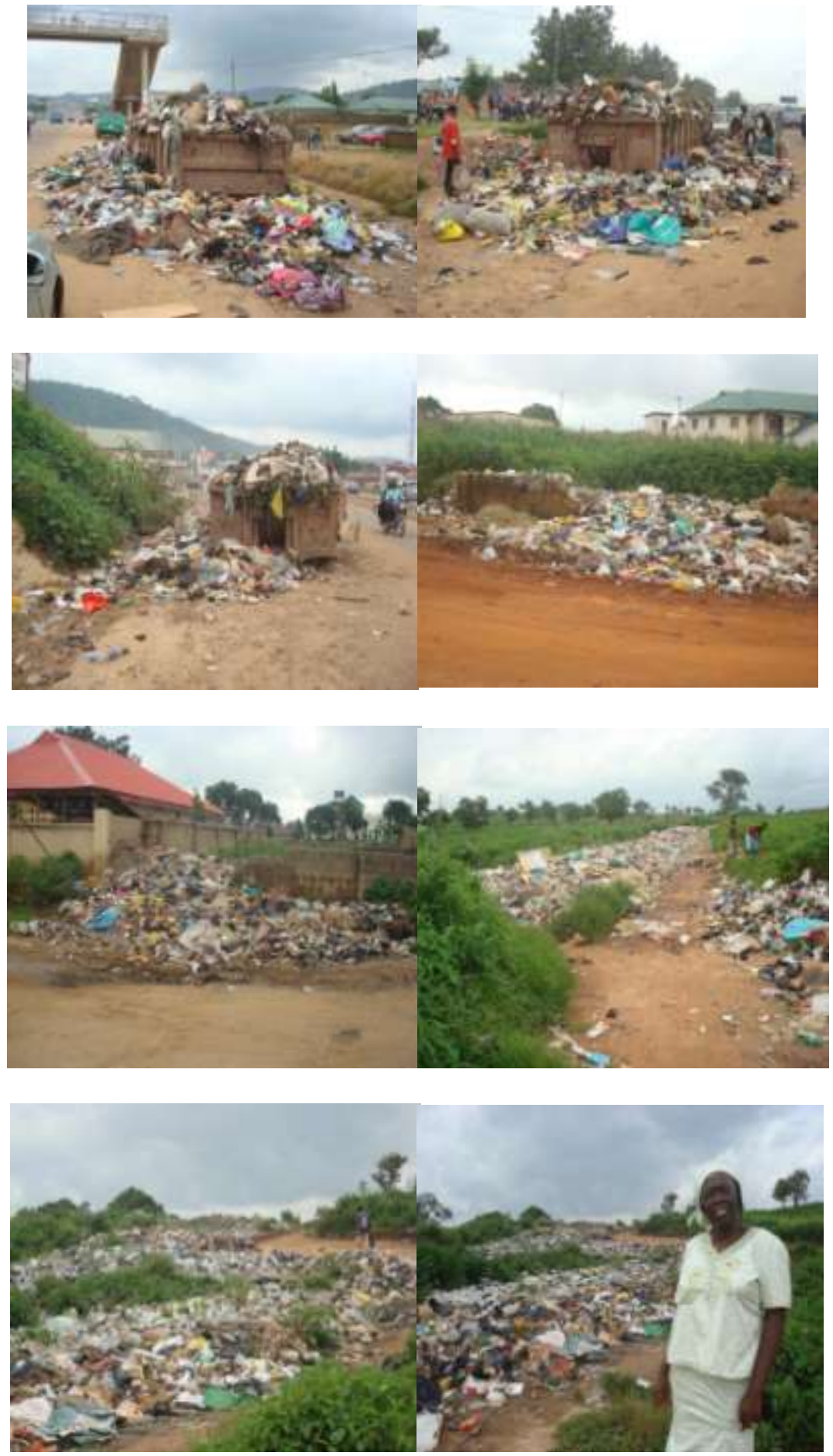

AMAC Karu District 

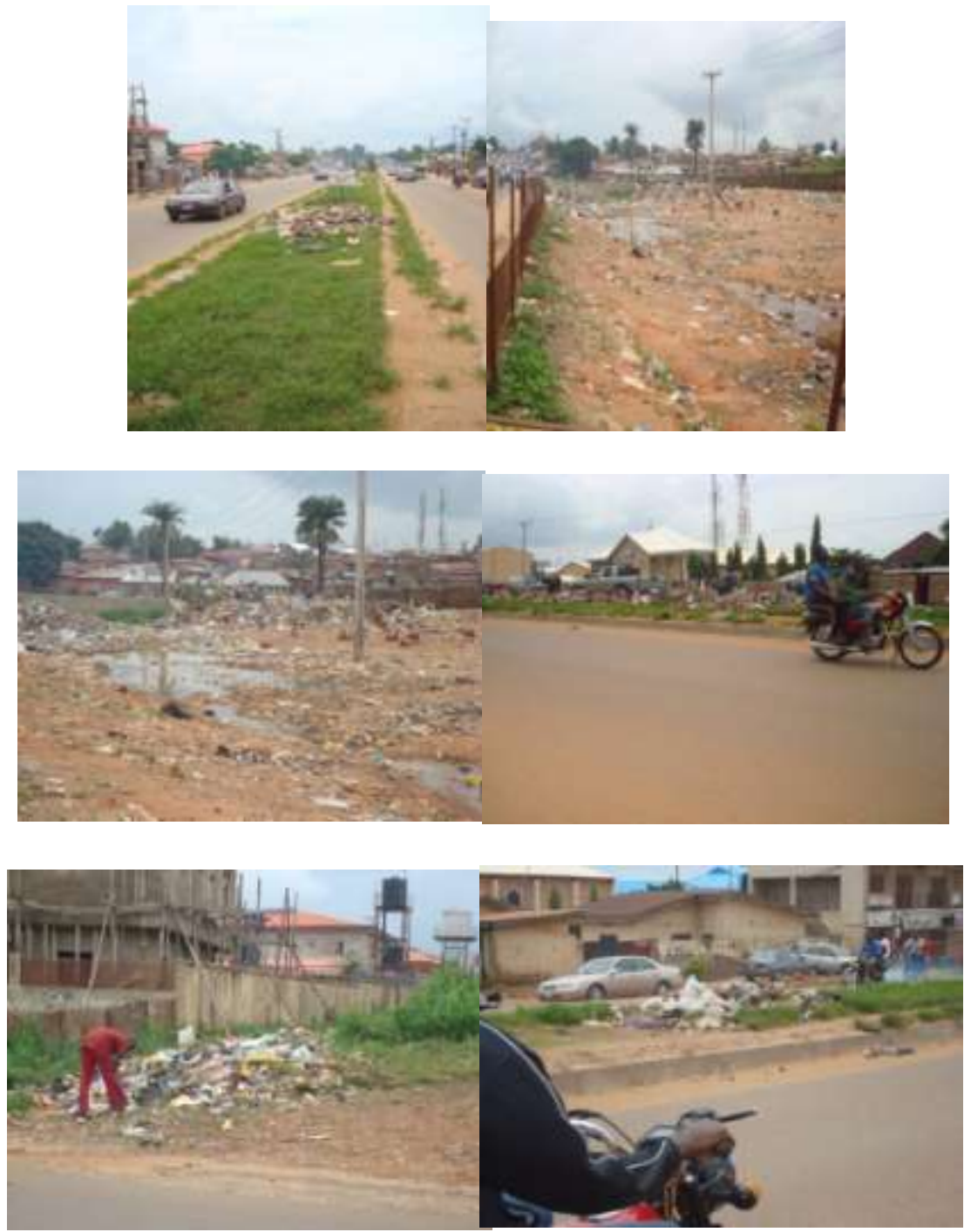

\section{AMAC Karshi District}
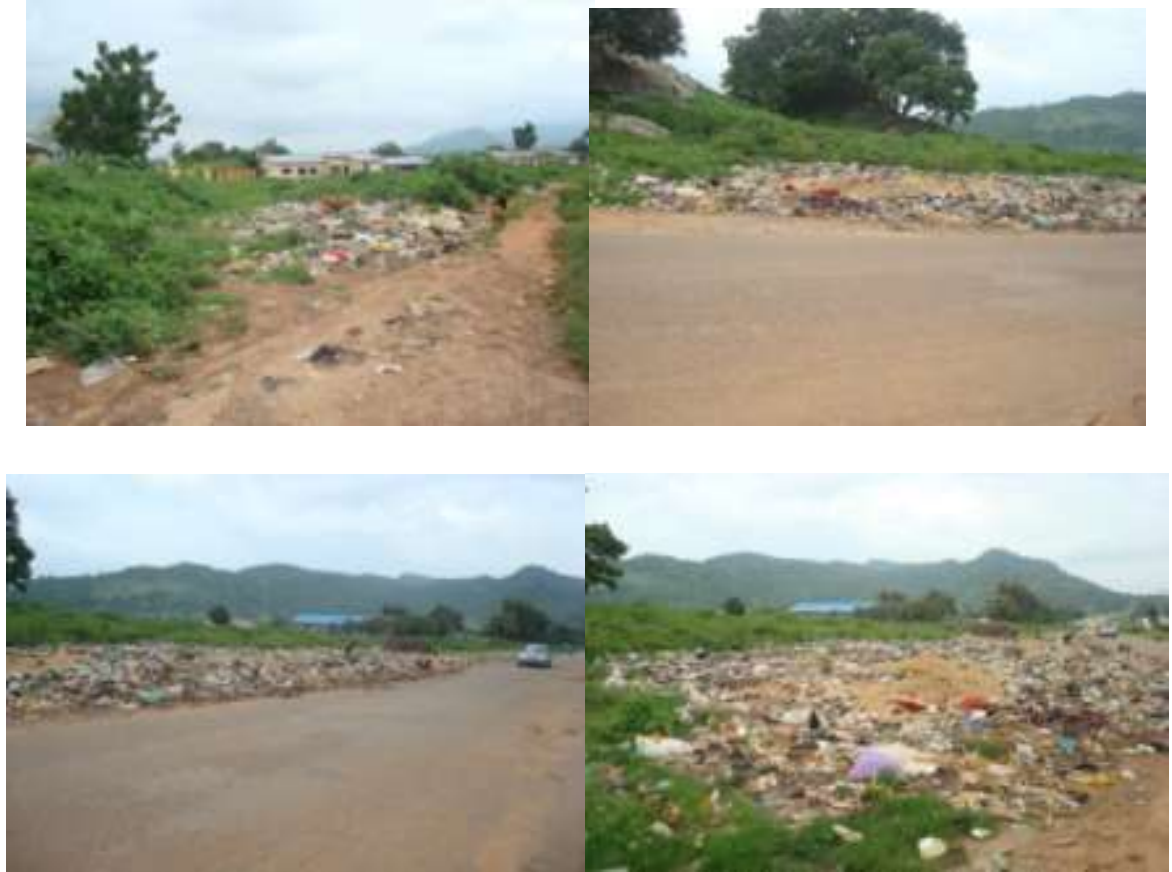
AMAC Federal Capital City
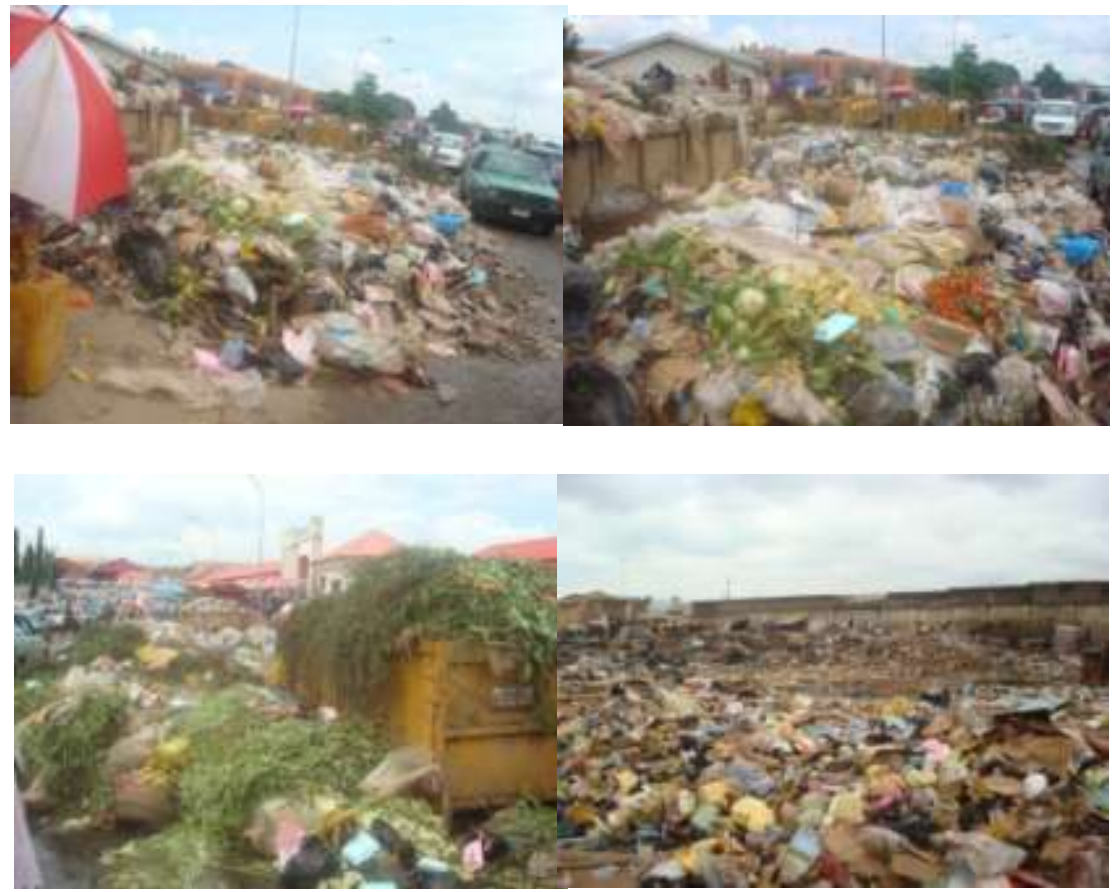

Utako Market Collection Point

Jabi Market Collection Point

Abaji Area Council
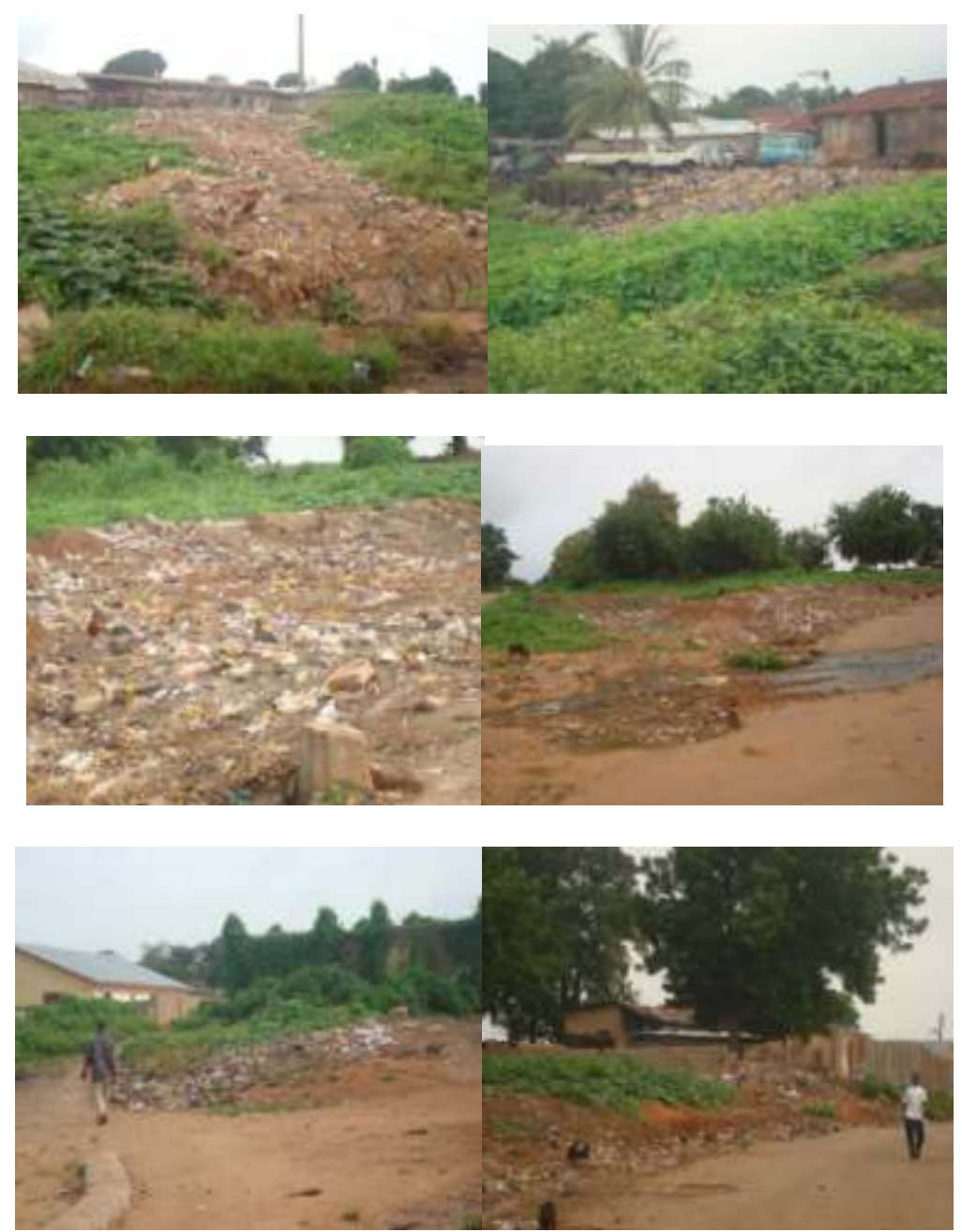

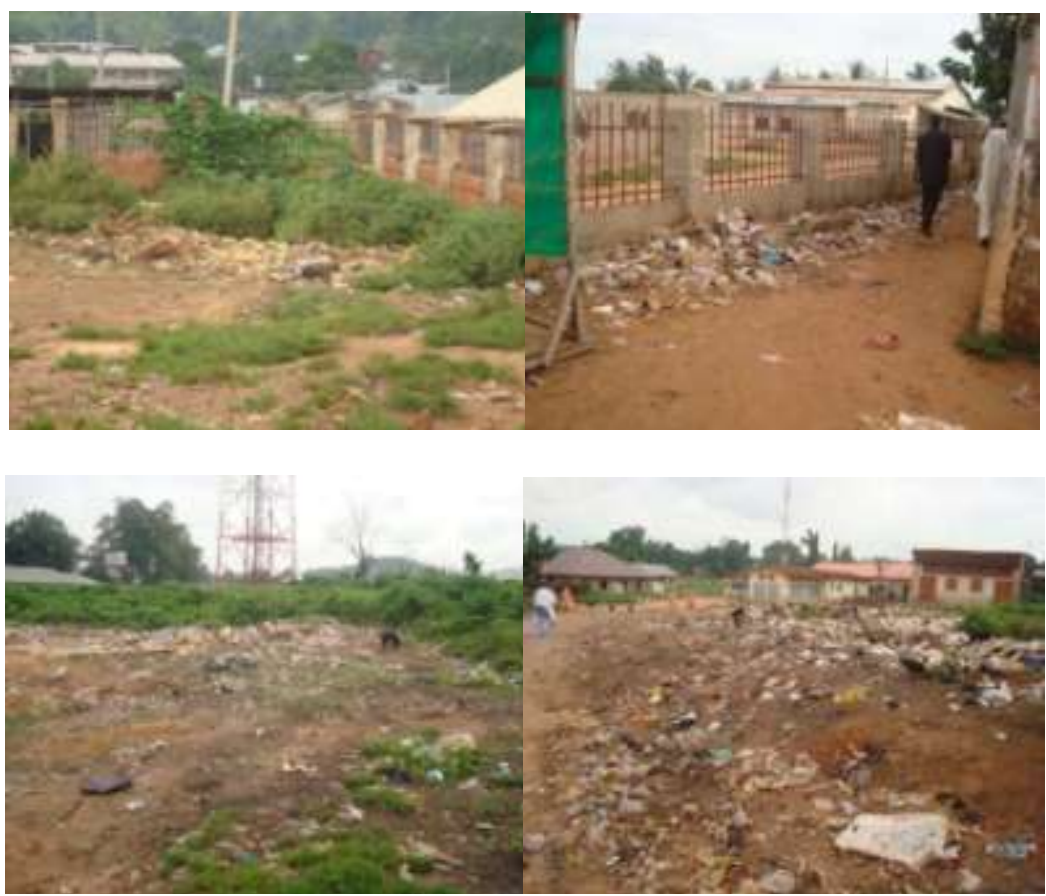

Bwari Area Council
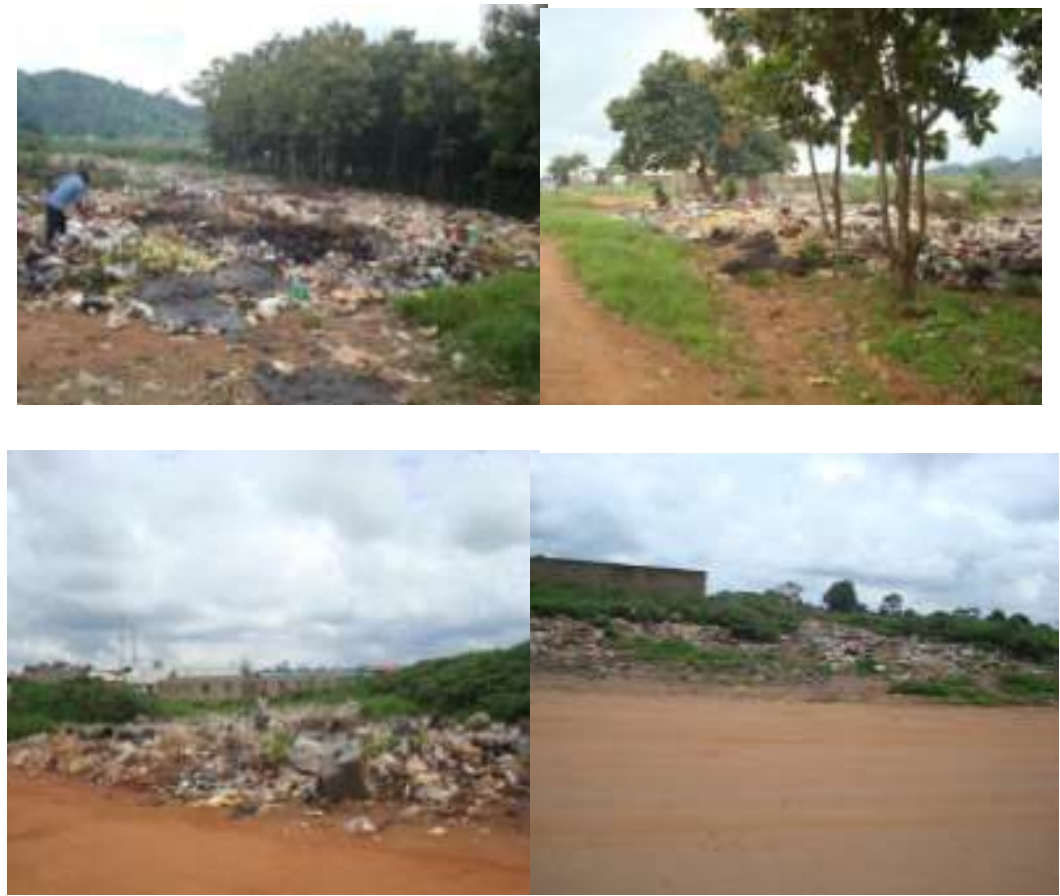

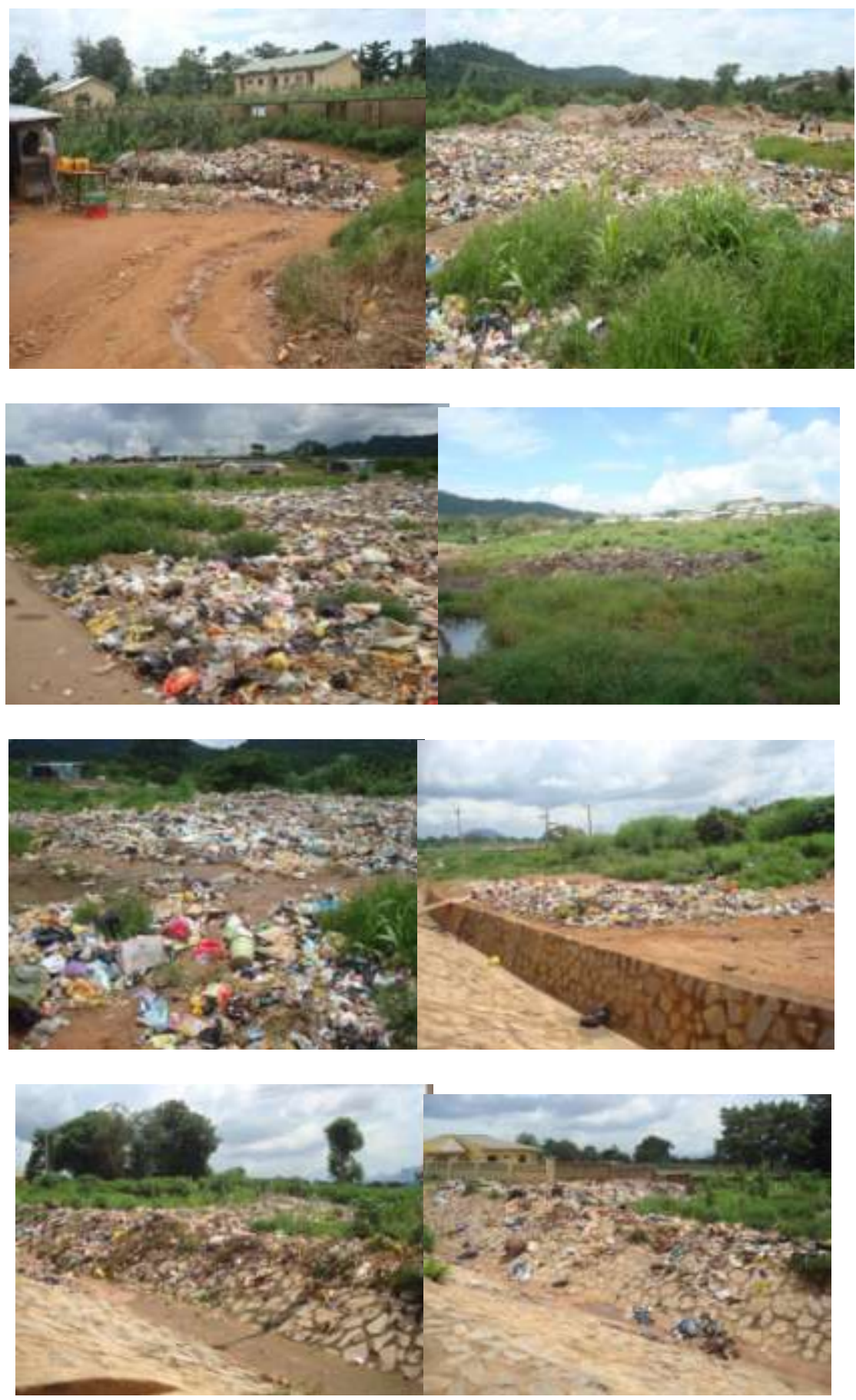

Gwagwalada Area Council

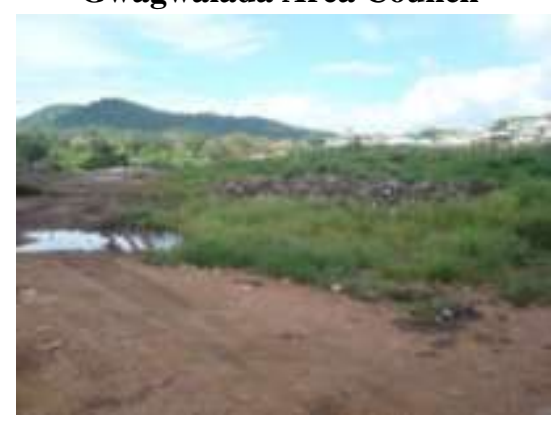




\section{Recommendations}

Due to indiscriminate littering and dumping Abuja, there is a need to upgrading collection points to mini transfer stations and Increase number of community bin in densely populated areas with daily evacuations during office hours to avoid causing traffic jams due to hauling truck. To ensure the success of the above recommendations frequent and periodic environmental awareness programmes using different mediums of communication. Toward changing the attitude of residents and policy makers with regards to environmental issues.

\section{Acknowledgement}

To the staff of Abuja Environmental Protection Board, Nigeria

\section{References}

[1] Abuja-Citiserve. (2004). Estimates of Waste Generation Volumes and Income Potential in Abuja. Population Abuja (English Edition), 805:1-29. http://www.slgpnigeria.org/uploads/File/805.pdf. Accessed. 16th April 2012

[2] Abulude, F. O., Obidiran, G. O. \&Orungbemi, S. (2007). Determination of Physio-chemical parameter and Trace metal contents of drink water sample in AkureNigeria.Electronic Journal of Environmental, Agricultural and Food Chemistry, 6(8):2298-2299.

[3] Achankeng, E. Globalization, Urbanization and Municipal Solid Waste Management in Africa (pp. 1-22). Africian Studies Association of Australasia and Pacific 2000 Conference Proceedings- African on a GlobalStage. 2003.

[4] Adedibu, A.A. (1985). "Comparative analysis of solid waste composition and generating in two cities of developing nation." The Environmentalist, 5 (2):123-127.

[5] Adekunle, I.M., Adekunle, A.A., Akintokun, A.K., Akintokun, P.O. \&Arowolo, T.A. (2011). Recycling of Organic Wastes through Composting for Land Applications: A Nigerian Experience. Waste Management \& Research, 29(6): 582-93.

[6] Agwu, M.O. (2012). Issues and Challenges of Solid Waste Management Practices in Port-Harcourt City, Nigeria- a behavioural perspective. Am. J. Soc. Mgmt. Sci., 3(2):83-92.

[7] Amfo-Out, R., Waife, D.D., AdjeiKwakwa, P.A. \&Akpah-Yeboah, S.(2012). Willingness to Pay for Solid Waste Collection in Semi-Rural Ghana: A Logit Estimation. International Journal of Multidisciplinary Research, 2(7):40-49.

[8] Banga, M., Lokina, R.B. \&Mkenda, A.F. (2011). Households' Willingness to Pay for Improved Solid Waste Collection Services in Kampala City, Uganda.The Journal of Environment Development, 20(4):428.

[9] Cohen, J.W. (1988). Statistical Power Analysis for the Behavioral Sciences(2nd edn). Hillsdale, NJ: Lawrence Erlbaum Associates.

[10] Fox, N., Hunn, A. \& Nigel Mathers, N. (2009). Sampling and Sample Size Calculation National Institute of Health Research. www.rds-eastmidlands.nihr.ac.uk. Accessed January $2^{\text {nd }} 2011$.

[11] Gomez, G., Meneses, M., Ballinas, L. \& Castells, F. (2009). Seasonal Characterization of Municipal Solid Waste (MSW) in the City of Chihuahua, Mexico. Waste Management, 28:2018-2024.

[12] Hoornweg, D. \&Bhada-Tata, P. The World Bank Urban Development Series Knowledge Paper: What a Waste: A Global Review on Solid Waste Management. March 2012, No. 15.

[13] Imam, A., Mohammed, B., Wilson, D.C. \& Cheeseman, R. (2008). Solid Waste management in Abuja, Nigeria. Waste Management, 2(28):468-472.

[14] Jacob, C. (1990). Things I have learned (so far). Cohen American Psychologist, 45 (12):1304-1312.

[15] Jalil, A. (2010). Sustainable Development in Malaysia : A Case Study on Household Waste Management. Sustainable Development, 3(3):91-102.

[16] Keser, S., Duzgun, S., \&Aksoy A. (2012). Application of Spatial and Non-Spatial Data Analysis in Determination of the Factors that Impact Municipal Solid Waste Generation Rates in Turkey. Waste Management, 32:359-71. 
[17] Khan, S. \&Fasial, M.N. (2008). An Analytical Network Process Model for Municipal Solid Waste Disposal Options. Waste Management, (28):1500-1508.

[18] Klundert, van de .A. \& Anschutz, J. (2001). Integrated Sustainable Waste Management- The Concept: Tools for Decision Makers, Experiences from the Urban Waste Expertise Programme (1995-2001). (A. Scheinberg, Ed.). Netherlands. Retrieved from www.waste.nl

[19] Kofoworola, O.F. (2007). Recovery and recycling practices in municipal solid waste management in Lagos, Nigeria. Waste Management, 27:1139-1143.

[20] Krejcie, R.V. \& Morgan, D.W. (1970) Determining Sample Size for Research Activities. Educational and Psychological Measurement, 30:607-610.

[21] Kumar, S., Bhattacharyya, J.K., Vaidya, A.N., Chakrabarti, T., Devotta, S. \&Akolkar, A.B. (2009b). Assessment of the Status of Municipal Solid Waste Management in Metro Cities, State Capitals, Class I Cities, and Class II Towns in India : An Insight. Waste Management, 29(2):883-895.

[22] Lalita, A. \&Sunita, A. (2011). Knowledge, Attitude and Practices regarding Waste Management in Selected Hostel Students of University of Rajasthan, Jaipur. International Journal of Chemical, Environmental and Pharmaceutical Research, 2(1):40-43.

[23] Latifah, A.M., Basri, H. \&Basri, A.N.E. (2008). UrusSisa: An Intelligent System for Integrated Solid Waste Management. Journal of Sustainable Development, 1(2): 39-46.

[24] Longe, E.O., Longe, O.O. \&Ukpebor, E.F. (2009). People's Perception on Household Solid Waste Management in Ojo Local Government Area in Nigeria.Iran. J. Environ. Health. Sci. Eng., 6(3):209-216.

[25] Momodu, N. S., Dimuna, K. O. \&Dimuna, J. E. (2011). Mitigating the Impact of Solid Wastes in Urban Centres in Nigeria. J Hum Ecol, 34(2):125-133.

[26] Nabegu, A.B. (2010). An Analysis of Municipal Solid Waste inKano Metropolis, Nigeria. J Hum Ecol, 31(2):111-119.

[27] NPC. (2012). National Population Commission Nigeria. Retrieved from www.population.gov.ng. Accessed $16^{\text {th }}$ April 2012.

[28] Ogbonna, D.N., Ekweozor, I.K.E. \&Igwe, F.U. (2002) Waste Management: A Tool for Environmental Protection in Nigeria. Ambio, 31(1):55-57.

[29] Ogu, V.I. (2000). Private Sector Participation and Municipal Waste Management in Benin City, Nigeria. Environment and Urbanization, 12(2):103-117.

[30] Ogwueleka, T.C. (2003). Analysis of Urban Solid Waste in Nsukka, Nigeria. Journal of Solid Waste Technology and Management, 29(4):239-246.

[31] Ogwueleka, T.C. (2009). Municipal Solid Waste Characteristics and Management in Nigeria. Iran J. Environ. Health Sci. Eng, 6(3):173-180.

[32] Ogwueleka, T.C. (2013). Survey of Household Waste Composition and Quantities in Abuja, Nigeria. Resources, Conservation and Recycling, 77:52-60.

[33] Ohakew, J., Nnorom, I.C. \&Iwueze, I.S. (2011). Survey of Attitude of Residents towards Environmental Deterioration in Nigeria and Factors Influencing their Willingness to Participate in Reducing the Trend: A Case Study of Waste Management. Trends in Applied Sciences Research, 6(2):154-164.

[34] Olanrewaju, O.O. \&Ilemobade, A.A. (2009). Waste to Wealth: A Case Study of the Ondo State Integrated Wastes Recycling and Treatment Project, Nigeria. European Journal of Social Sciences, $8(1): 7-16$.

[35] Olorunfemi, F.B. (2009). Willingness to Pay for Improved Environmental Quality among Residents Living in Close Proximity to Landfills in Lagos Metropolis, Nigeria. African Research Review, 3(1):97110.

[36] Olufayo, O. \&Omotosh, B.J. (2007). Waste Disposal and Management in Ado-Ekiti, Nigeria. The Social Science, 2(2):111-115.

[37] Periathamby, A, Hamid, F.S. \&Khidzir, K. (2009). "Evolution of Solid Waste Management in Malaysia: Impacts and Implications of the Solid Waste Bill, 2007," Journal of Mater Cycles Waste Management, 11:96-103.

[38] Rahji, M.A.Y \&Oloruntoba, E.O. (2009). Determinants of Households' Willingness-to-Pay for Private Solid Waste Management Services in Ibadan, Nigeria. Waste Manag Res, 27:961.

[39] Rushton, L. (2003). Health Hazards and Waste Management. British Medical Bulletin, 68:183-197. 
[40] Sekaran, B.R. (2010). Research Methods for Business: A Skill Building Approach.UK: John Wiley \& Sons.

[41] Shapan, C.M. \& Mohammad, R.K. (2012).Urban Solid Waste Management: A Study on ComillaCityCorporation.Journal of Economics and Sustainable Development, 3(6):53-61.

[42] Sumukwo, J., Kiptui, M. \&Cheserek, G.J. (2012). Economic Valuation of Improved Solid Waste Management in Eldoret Municipality. Journal of Emerging Trends in Economics and Management Sciences, 3(6):962-970.

[43] Tchobanoglous, G., Theisen, H. \& Vigil, S. (1993). Integrated Solid Waste Management: Engineering Principles and Management Issues. McGraw-Hill International Edition, Singapore.

[44] UNEP (2002). Waste generation - how many million tone.http://www.vitalgraphics.net/waste/html_file/08-09_waste_generation.html. Accessed October $2^{\text {nd }}$ 2011.

[45] UNEP (2009a). Developing Integrated Solid Waste Management Plan Training Manual: ISWM Plan. United Nations Environmental Programme, 4. Retrieved from www.unep.org. Accessed October $2^{\text {nd }}$ 2011.

[46] UNEP (2009b). Developing Integrated Solid Waste Management Plan Training Manual: Waste Characterization and Quantification with Projections, 1. www.unep.org. Accessed October $2^{\text {nd }} 2011$.

[47] Visvanathan, C. \&Trankler, J., Municipal Solid Waste Management in Asia: A Comparative Analysis. Presented at the National Workshop on Sustainable Solid Waste Landfill Management in Asia), Bangkok, Thailand, 29 - 30 September 2003.

[48] Zamorano, M., Molero, E., Grindlay, A., Rodriguez, M., Hurtado, A. \&Calvo, F. (2009). A Planning Scenario for the Application of Geographical Information Systems in Municipal Waste Collection: A Case of Churriana de la Vega (Granada, Spain). Resource, Conservation and Recycling, 54:123-133. 